\title{
塩化亜鉛の共存下アセトフェノンの白金電極を用いる電解還元反応. 1ーフェニルェタノールの高選択的合成
}

\author{
池田 嘉一 \\ Highly Selective Formation of 1-Phenylethanol \\ Yoshikazu IKEDA \\ Received July 11,1990 ; Accepted September 25, 1990
}

Electroreduction of Acetophenone on Platinum Electrode in the Presence of Zinc Chloride.

The influence of zinc chloride in the electroreduction of acetophenone (I) on a platinum electrode was investigated from the preparation view point. Zinc chloride was found to enhance the yield of 1-phenylethanol (II) remarkably depending on the electrolysis conditions. This effect is explained viewing the complex formation between I and the zinc ion formed by the dissolution of zinc electrodeposited at the electrode surface in acidic aqueous-alcoholic solutions. The highest yield of II $(97 \%)$ was obtained when I $\left(8.3 \times 10^{-3} \mathrm{~mol}\right)$ was electrolyzed in a mixed solvent of $50 \mathrm{ml}(2 \mathrm{M} \cdot \mathrm{HCl}: \mathrm{EtOH}: \mathrm{n}-\mathrm{BuOH}=2.5: 1.0$ : $1.5 \mathrm{v} / \mathrm{v})$ containing zinc chloride $\left(19.6 \times 10^{-2} \mathrm{~mol}\right)$ by passing $20 \mathrm{~F} / \mathrm{mol}$ of electricity with a constant current density of $-16 \mathrm{~mA} / \mathrm{cm}^{2}$. The present method was successfully applied to other ketones and aldehydes, and corresponding alcohols were obtained in the yield rangeing from 3 to $97 \%$. The yield depends strongly on the steric effect rather than the electronic effect of substrates.

\section{1 緒 言}

カルボニル化合物を電解還元するに際し，遷移金属八 ロゲン化物を共存させたメディエイター成心に興味か洔 たれている. Martinet ら”非水中性溶媒中夕口ム(III) を其存させたベンゾフェノン, アセ卜フェノン, アンス ロン，及びフルオレノン等のカルボ二ル化合物がその還 元過程でケトンークロム（II）錯体またはケチルークロム （II）錯体を生成することをポーラログラフィーにおい て明らかにしこのものはカルボニル化合物自体の還元 電位よりも僅かに負の電位で還元できることを報告した。

カルボニル化合物の電解還元二量化反応に関しては数 多くの報告例があり，この反応は電解条件，特に溶液の $\mathrm{pH}$ と電極に強く依存する特性が知られている、ベンゾ〉 ェノンは酸性溶媒中で二量化物のベンズピナコールを選 択的に，中性溶媒中ではベンズヒドロールを与え，その

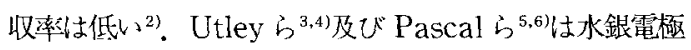
を使用し，ベンズヒドロールを与えるベンゾフェノンの 還元条件下にクロム (III) ないしはマンガン (II) を共 存させれば二量化物ベンズピナコ一ルを優先的に与える ことを報告している。またアアセトフェノン [I］は酸

化学技術研究所・精密化学部 (テ 305 茨城県つ〈ば東東 1-1) National Chemical Laboratory for Indusory (Higashi, Tsukuba, Ibaraki 305)

Key words: Electroreduction of Acetopcenone, (Zinc Mediator, 1 -Phenylethanol, Ketone and Aldehyde

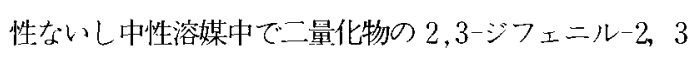
ーブタンジオール [III] を選択的に，アルカリ性溶媒中で は1ーフェニルエタノール [II] とIIIの混合物を与える2! 我々は先に, 酸性アルコール溶媒中, アンチモン (III) を共存させたIの鉛電極による還元反応が，IIを高収率 で与えることを報告しだ．また，Petitら流非水溶媒 中，タングステン (VI) を共存させた I の白金電極によ る還元反応が, 促来報告されなかった 1,2 -ジメチルスチ ル゙ンを与えることを報告した。この様に電解系に金属 壏を共存させたメディエイ夕一反応においては，生成物 選択性ないしは特異性を与之る等，種々の反応か期待さ れている。

今回著者は, 酸性アルコール溶媒中て塩化亜鉛共存下 にIの白金電極による還元反応を検討したところ，従来 合成が困難とされる還元生成物IIが高収率で得られるこ とを見いだした，本報告では合成的観点からIの生成に 対子る最適電解条件の確立と，このち法の有用性につい て検討した結果を述べる。

\section{2 実 験}

\section{1 試薬}

塩酸、エ夕ノール及びnーブタノールは市販特級品をそ のまま使用した，そのほかの試薬類は市販特級品を蒸留 または再結晶精製したものを使用した。 


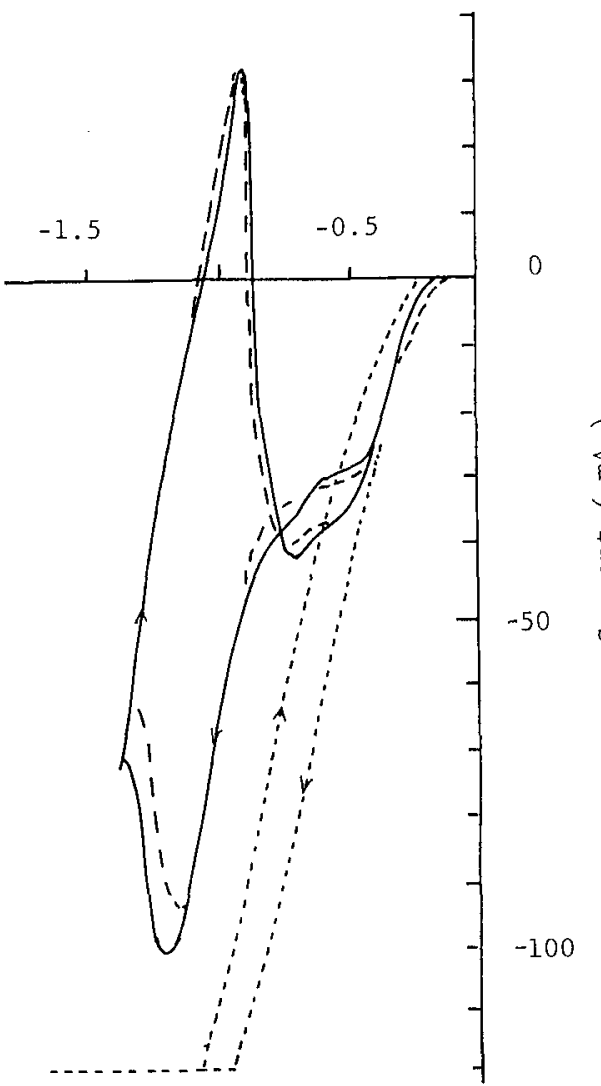

Potential / V vs. Ag/AgCl

Fig. 1 Typical cyclic voltammograms of 125 $\mathrm{mM} \mathrm{ZnCl}_{2}$ in the mixed solvent with use of a $\mathrm{Pt}$ electrode.

$2 \mathrm{M}-\mathrm{HCl}+\mathrm{EtOH}+\mathrm{n}-\mathrm{BuOH}$

$2 \mathrm{M}-\mathrm{HCl}+\mathrm{EtOH}$

$2 \mathrm{M}-\mathrm{HCl}+\mathrm{EtOH}+\mathrm{n}-\mathrm{BuOH}$ (Blank)

Sweep rate $; 100 \mathrm{mV} / \mathrm{s}$.

\section{2 電解装置}

電解合成は北壮電丁製 HA-105 ポテンショ/ガルバ/ス タットを前いて行なった。電気量の測定は北斗電丁製 HF201 クーロンメーターを执い。電解セルは除極公に窣素 導大管を備えた $200 \mathrm{ml}$ の H 型がラスセルを使用した。 電極は除極，陽極共に日金板 $\left(6 \mathrm{~cm}^{2}\right)$ を使用した。

\section{3 電解方法}

陰極窒には $\mathbf{I} の 1.0 \mathrm{~g}\left(8.3 \times 10^{-3} \mathrm{~mol}\right)$ と所定星の $\mathrm{ZnCl}_{2}$ を 2 規走塩酸：エ夕ノール： $\mathrm{n}$-ブタノール (2.5： $1.0: 1.5 \mathrm{v} / \mathrm{v})$ の混合溶媒に溶解した $50 \mathrm{ml}$ の溶液を, 陽極室には混合浴媒のみ $50 \mathrm{ml}$ を入れた。除树室を窒素 で 30 分間置換したのち,マグネチックスターラーて摚拌 しながら窒温下，所定の電流密度で電解を行なった，反

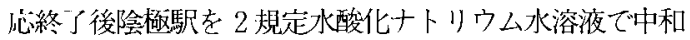
し, 次いでエーテル $100 \mathrm{ml} て ゙$ 抽山した。エーテル溶液を 無水硫酸ナトリウムで乾燥し, 溶媒をエバポレーターで 除去した後，残留物を GLCで分析した。

\section{4 生成物の確認と定量}

分析は $10 \%$ Thermon-3000 (担体 Celite 545 AS) を充填した長さ $2 \mathrm{~m}$ 内内径 $3 \mathrm{~mm}$ のガラスカラムを使用 し，島津 GC-6 A 型がスクロマトグラフィーによった. $\mathrm{He}: 40 \mathrm{ml} / \mathrm{min} \quad 50 \sim 230^{\circ} \mathrm{C}\left(10^{\circ} \mathrm{C} / \mathrm{min}\right)$. 反応率およ び生成物組成は末反応物，生成物のピーク面積比から単 純に計算して求めた。

\section{3 結果と考察}

\section{1 塩化亜鉛共存下 $\mid \sigma$ 睘元反応}

Figure 1 亿㙐酸 $(2.0 \mathrm{M})$ を令吉 $50 \%$ 水一多ノール 溶媒中に壏化带鉛 $(125 \mathrm{mM})$ を溶解した溶液のサイクリ ックボルタモグラムを示した。 $-0.2 \mathrm{~V}$ 付近で水素がスが 発生し,塩化平鈆の電流ピークはー1.13Vに認如られた。 ピーク対称性は塩化車鉛及び塩酸濃度によって著しく影 響され，還元電位は塩化要鉛の濃度を増大させると貴側

Table 1 Cyclic voltammetric date of $\mathrm{ZnCl}_{2}$ reduction.

\begin{tabular}{|c|c|c|c|c|c|c|c|}
\hline \multirow[b]{2}{*}{ Run } & \multirow{2}{*}{$\begin{array}{c}\mathrm{ZnCl}_{2} \\
\times 10 \\
(\mathrm{M})\end{array}$} & \multicolumn{2}{|c|}{$0.5 \mathrm{~N}-\mathrm{HCl}-\mathrm{EtOH}$} & \multicolumn{2}{|c|}{ 1. $0 \mathrm{M}-\mathrm{HCl}-\mathrm{EtOH}$} & \multicolumn{2}{|c|}{ 2. $0 \mathrm{M}-\mathrm{HCl}-\mathrm{EtOH}$} \\
\hline & & $\begin{array}{c}\text { Potential }^{a)} \\
(-\mathrm{V})\end{array}$ & $\begin{array}{c}\text { Current } \\
(\mathrm{A} / \mathrm{C}) \\
\end{array}$ & $\begin{array}{c}\text { Potential }^{a 1} \\
(-V) \\
\end{array}$ & $\begin{array}{c}\text { Current }^{\mathrm{b}}{ }^{\prime} \\
(\mathrm{A} / \mathrm{C}) \\
\end{array}$ & $\begin{array}{c}\text { Potential" } \\
(-V)\end{array}$ & $\begin{array}{c}\text { Current }{ }^{b)} \\
(\mathrm{A} / \mathrm{C}) \\
\end{array}$ \\
\hline 1 & 2.49 & 0.938 & 4.9 & 0.972 & 2.3 & 1. 038 & 0.7 \\
\hline 2 & 1. 67 & 0.951 & 3.1 & 1.015 & 1.3 & 1. 063 & 0.4 \\
\hline 3 & 1. 25 & 0.988 & 1.9 & 1.025 & 1. 1 & 1. 125 & 0.3 \\
\hline 4 & 0.84 & 1.038 & 1. 1 & 1.095 & 0.6 & 1. 172 & 0.2 \\
\hline 5 & 0.34 & 1.088 & 0.5 & 1. 226 & 0.2 & $*$ & - \\
\hline 6 & 0.21 & 1. 175 & 0.2 & $*$ & & $*$ & - \\
\hline 7 & 0.10 & $*$ & - & $*$ & & $*$ & -- \\
\hline
\end{tabular}

Cyclic voltammetric measurements were carried out using a Pt wire electrode in various aqueous ethanol at a scan rate of $0.1 \mathrm{Vs}^{-1}$.

a) $\mathrm{V}$ vs $\mathrm{Ag} / \mathrm{AgCl}, *$ Unable to observe.

b) $\mathrm{A} / \mathrm{C}$ refers to the ratio of anodic peak current to cathodic one. 
にシフトした。結果を Table 1に示した。

つぎに, 锰化再鉛 $2.3 \mathrm{~g}\left(1.6 \times 10^{-2} \mathrm{~mol}\right)$ との 1.0 $\mathrm{g}\left(8 \times 10^{-3} \mathrm{~mol}\right)$ を溶解した溶液 $(50 \mathrm{ml})$ のマクロ定 電隹電解 $(-1.02 \mathrm{~V})$ を行った，電極には白金を使用し, 通電量を $4 \mathrm{~F} / \mathrm{mol}$ とした，その結果，還元生成物として IIが $58 \%$ の収率で得られた。他は未反応原料のIであっ た。通電量をさらに增大させるとIIの外にIIIが生成した。 一方，程化車鉛を含まない場合には通電量 $8 \mathrm{~F} / \mathrm{mol}$ でも IIのみをえ，その收率は $5 \%$ と低かった。これらの結 果より，塩化車鉛は反応を促進させる特性を有し，しか

$$
\begin{aligned}
& \mathrm{R} \\
& \underset{\substack{\mathrm{C} \\
\mathrm{R}^{\prime}}}{\mathrm{C}} \underset{\mathrm{Pt}, \mathrm{in} \mathrm{Zn}^{2+}}{\longrightarrow} \\
& \begin{array}{ccc}
\mathrm{R} & \mathrm{R} & \mathrm{OH} \\
\mathrm{I} & \mathrm{I} \\
\mathrm{R}^{\prime}-\mathrm{C}-\mathrm{OH} & \mathrm{R}^{\prime}-\mathrm{C}-\mathrm{C}-\mathrm{R}^{\prime} \\
\mathrm{H} & \mathrm{O} \quad \mathrm{l} \\
\mathrm{H} & \mathrm{OH} \quad \mathrm{R}
\end{array} \\
& \mathrm{R}=\mathrm{Ph}
\end{aligned}
$$

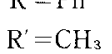

$$
\begin{aligned}
& \text { II }
\end{aligned}
$$

もこの特性は電解条件に強く依存することが分かった。

そこで本反応を合成的な観点からさらに詳細に検討した。

\subsection{1 高選択的生成に対する電解条件の検討}

以後の検討は総て定電流法を用いて行なった，電流密 度, 塩化西鉛共存量, 温度, 通電量, 及び電極の種類の 生成物IIに及ほ影響について検計し，結果を Table 2 に示した。

IIの選护的生成は還元電流密度が $16 \mathrm{~mA} / \mathrm{cm}^{2}$ より小さ い領域(Runs 8～10)，塩化和鉛の共存量が基質 Iに対 して2倍モル以下（Runs 14，15），温度が空温域，通 䉓量が $3.9 \mathrm{~F} / \mathrm{mol}$ 以下(Runs $10 ， 20 ， 21)$, 電極が白 金であるときに得られる。しかし，IIの最高収率は $50 \%$

\begin{tabular}{|c|c|c|c|c|c|c|c|}
\hline \multirow[b]{2}{*}{ Run } & \multirow{2}{*}{$\begin{array}{l}\text { Cathode } \\
\text { material }\end{array}$} & \multirow{2}{*}{$\begin{array}{l}\text { Current } \\
\text { density } \\
\left(-\mathrm{mA} / \mathrm{cm}^{2}\right)\end{array}$} & \multirow{2}{*}{$\begin{array}{c}\mathrm{ZnCl}_{2} \\
(\mathrm{mmol})\end{array}$} & \multirow{2}{*}{$\begin{array}{c}\text { Temp. } \\
\text { (C) }\end{array}$} & \multirow{2}{*}{$\begin{array}{c}\text { Electricity } \\
\text { passed }^{\text {al }} \\
(\mathrm{F} / \mathrm{mol})\end{array}$} & \multicolumn{2}{|c|}{$\begin{array}{c}\text { Yield } \\
(\%)\end{array}$} \\
\hline & & & & & & II & III \\
\hline 8 & $\mathrm{Pt}$ & 13 & 16.8 & R.t. & 3.9 & 43 & 0 \\
\hline 9 & $\mathrm{Pt}$ & 15 & 16.8 & R.t. & 3.9 & 44 & 0 \\
\hline 10 & $\mathrm{Pt}$ & 16 & 16.8 & R. t. & 3.9 & 50 & 0 \\
\hline 11 & Pt & 17 & 16.8 & R. t. & 3.9 & 30 & 62 \\
\hline 12 & $\mathrm{Pt}$ & 18 & 16.8 & R. t. & 3.9 & 28 & 62 \\
\hline 13 & $\mathrm{Pt}$ & 20 & 16.8 & R.t. & 3.9 & 25 & 66 \\
\hline 14 & $\mathrm{Pt}$ & 16 & 4.3 & R.t. & 3.9 & 12 & 0 \\
\hline 15 & Pt & 16 & 8.4 & R.t. & 3.9 & 18 & 0 \\
\hline 16 & $\mathrm{Pt}$ & 16 & 22.5 & R. t. & 3.9 & 19 & 79 \\
\hline 17 & $\mathrm{Pt}$ & 16 & 33. 6 & R.t. & 3.9 & 17 & 81 \\
\hline 18 & $\mathrm{Pt}$ & 16 & 16.8 & 0 & 3.9 & 9 & 86 \\
\hline 19 & $\mathrm{Pt}$ & 16 & 16.8 & 40 & 3. 9 & 7 & 91 \\
\hline 20 & $\mathrm{Pt}$ & 16 & 16.8 & R.t. & 2.0 & 18 & 0 \\
\hline 21 & $\mathrm{Pt}$ & 16 & 16.8 & R.t. & 3.0 & 34 & 0 \\
\hline 22 & $\mathrm{Pt}$ & 16 & 16.8 & R. t. & 6.0 & 49 & 42 \\
\hline 23 & $\mathrm{Pt}$ & 16 & 16.8 & R. t. & 8.0 & 59 & 40 \\
\hline 24 & $\mathrm{Zn}$ & 16 & 0.0 & R. t. & 3.9 & 5 & 88 \\
\hline 25 & $\mathrm{Pd}$ & 16 & 16.8 & R.t. & 3.9 & 15 & 81 \\
\hline 26 & $\mathrm{Cd}$ & 16 & 16.8 & R.t. & 3. 9 & 12 & 87 \\
\hline 27 & $\mathrm{Ni}$ & 16 & 16.8 & R.t. & 3.9 & 11 & 86 \\
\hline 28 & $\mathrm{Cu}$ & 16 & 16.8 & R.t. & 3.9 & 10 & 85 \\
\hline 29 & $\mathrm{~Pb}$ & 16 & 16.8 & R.t. & 3.9 & 7 & 90 \\
\hline 30 & $\mathrm{Hg}$ & 16 & 16.8 & R.t. & 3.9 & 2 & 96 \\
\hline
\end{tabular}
を超えなかった。

IIIの副生はより大きな電流密度 (Runs 11〜13)，過 剩量の塩化覀鉛共存下（Runs 16，17），室温より低い

Table 2 Electroreduction of $\mathrm{I}$ in the presence of zinc chloride.

Reductions were performed by using I $(8.3 \mathrm{mmol})$ and prescribed amount of $\mathrm{ZnCl}_{2}$ in a mixed solvent $(2 \mathrm{M}-\mathrm{HCl}: \mathrm{EtOH}=2.5: 2.5 \mathrm{~V} / \mathrm{V})$ of $50 \mathrm{ml}$ in a divided cell.

a) Electricity passed per mol of the substrate.

b) Determined by GLC. 
Table 3 Electroreduction of I on Pt cathode in the presence of zinc chloride.

\begin{tabular}{|c|c|c|c|c|}
\hline \multirow[t]{2}{*}{ Run } & \multirow{2}{*}{$\begin{array}{c}\text { Solvent } \\
(\mathrm{ml})\end{array}$} & \multirow{2}{*}{$\begin{array}{l}\text { Electricity } \\
\text { passed } \\
\quad(\mathrm{F} / \mathrm{mol})\end{array}$} & \multicolumn{2}{|c|}{$\begin{array}{l}\text { Yield } \\
(\%)\end{array}$} \\
\hline & & & II & III \\
\hline 31 & 1. $5 \mathrm{M}-\mathrm{HCl}: \mathrm{EtOH}=25.0: 25.0$ & 8 & 8 & 92 \\
\hline 32 & 2. $5 \mathrm{M}-\mathrm{HCl}: \mathrm{EtOH}=25.0: 25.0$ & 8 & 48 & 0 \\
\hline 33 & $3.0 \mathrm{M}-\mathrm{HCl}: \mathrm{EtOH}=25.0: 25.0$ & 8 & 39 & 0 \\
\hline 34 & 1. $.5 \mathrm{M} \quad \mathrm{HCl}: \mathrm{EtOH}=33.0: 17.0$ & 8 & 21 & 72 \\
\hline 35 & 11. $2 \mathrm{M} \cdots-\mathrm{HCl}: \mathrm{EtOH}=4.5: 45.5$ & 8 & 26 & 0 \\
\hline 36 & 11. $2 \mathrm{M}-\mathrm{HCl}: \mathrm{MeOH}=4.5: 45.5$ & 8 & 21 & 0 \\
\hline 37 & 11. $2 \mathrm{M}-\mathrm{HCl}: \mathrm{n}-\mathrm{PrOH}=4.5: 45.5$ & 8 & 24 & 35 \\
\hline 38 & 11. $2 \mathrm{M}-\mathrm{HCl}: \mathrm{n}-\mathrm{BuOH}=4.5: 45.5$ & 8 & 46 & 0 \\
\hline 39 & 2. $0 \mathrm{M}-\mathrm{HCl}: \mathrm{EtOH}: \mathrm{n}-\mathrm{Bu}=25: 10: 15$ & 8 & 55 & 0 \\
\hline 40 & 2. $0 \mathrm{M}-\mathrm{HCl}: \mathrm{EtOH}: \mathrm{n}-\mathrm{Bu}=25: 10: 15$ & 14 & 90 & 0 \\
\hline 41 & 2. $0 \mathrm{M}-\mathrm{HCl}: \mathrm{EtOH}: \mathrm{n}-\mathrm{Bu}=25: 10: 15$ & 20 & 97 & 0 \\
\hline 42 & 2. $0 \mathrm{M} \cdot \mathrm{HCl}: \mathrm{EtOH}: \mathrm{n}-\mathrm{Bu}=25: 10: 15$ & 27 & 97 & 0 \\
\hline 43 & 2. $0 \mathrm{M} \quad \mathrm{HCl}:$ EtOH $: n-B u=25: 10: 15$ & 27 & 9 & c \\
\hline
\end{tabular}

Reductions were performed by using I $(8.3 \mathrm{mmol})$ and $\mathrm{ZnCl}_{2}(16.8 \mathrm{mmol})$ in a mixed solvent (50 $\left.\mathrm{ml}\right)$ at $-16 \mathrm{mAcm}^{-2}$ on Pt cathode in a divided cell.

Reduction in run 43 was performed under conditions in the absence of $\mathrm{ZnCl}_{2}$.

温度，高い温度 (Runs 18，19)，過剩量通電時 (Runs 22,23）ならびにパラジウム, カドミウム, ニッケル, 銅, 鉛, 水䤵 (Runs 25 30) 等の電極を使用したとき 認められた。これらの条件下では針状晶状に成長する金 属車鉛の生成が電極板上に観察され，通電量の增大と共 に電析金属亜鉛の量が增加した，IIが選択的に生成する 条件下では亜鉊の電析は認められなかった。また，亚鉛 金属板を使用した塩化亜鉛を含まない場合の還元結果は IIIを優先的に与之た(Run 24)。これらのことより，本 反忘におけるIIIの副生は電析した金属要鉛の特性が反応 に大きく関与した結果であることが分かった。

IIの収率向、上を図るべくさらに塩酸濃度, 水一エ夕ノー ル混合比率 アルコールの種類等の影響を検討した．結 果をTable 3 に示した。低濃度の塭酸溶液系ではIIの 生成が優先する(Run 31)。高浱度においてはIIIの副生 は認められなかったが、末反応の Iが $50 \%$ 以上も回収き れまたI原収率も濃度力増大寸るにつれて減少した(Runs 32，33). 壏酸濃度としては 2 規定が最も適していること が分かった(Run 10)。そこで 2 規定塩酸 $25 \mathrm{ml}$ 中に会 まれる塩酸モ儿濃度に，等しい程酸量を含有した，各種 混合比率氻らなる水一多人儿溶媒樂の影響を検討した。 水か相対的に多い場合（Run 34）にはIIIか優先的に生 し，エ夕ノ一ルを増すと(Run 35)，IIIの生成は見られ

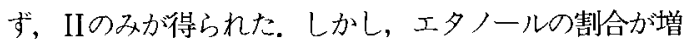
えてもIの生成收率はほとんど変わらなかった。混合比 率が 1 の時にIIか好収率てて得られた（Run 10)。アルコ 一ルの種類の影響を闰様に検討したところ, n-ブ夕ノール
が好結果を与えた(Run 38)。その効果の增大寸る順序 はn-ブタノール>エタノール〉メタノール>n-プロパノ 一ルであった $\mathrm{n}$ プロパノールではIIIの副生を伴った(Run $37)$.

n一ブタノ一ルの水に対寸る溶解性を考虑し, 2 規定塩酸： エタノール：n-ブタノールの混合溶媒系を用いて, 通電量, 塩化覀鉛の効果を検討した(Runs 39－43)。との結果， n-ブタノールの添加はIIを選択的に与之(Runs 23,39), その収率は通電量の增大によって向上した。 また本浴媒 系では，塩化西鉛を含まない場合のIIの収率は大過剩の 通電量下にあっても $9 \%$ \%あり，残りはすへて原料回収 であった（Run 43）。

IIIの副生を抑之，IIの収率增大に関わる種々の因子の 影響を検討した結果，溶媒系へのnーブタノールの添加が 最も効果的であることか汾かった．IIの最高収率(97\%) は電極に白金電極を使用し，壏化西鉛をIに対して 2 倍 モル溶解させた 2 規定塭酸：エタノール：n-ブタノール の混合溶液中で $16 \mathrm{~mA} / \mathrm{cm}^{2} の$ 電流密度のもとに $20 \mathrm{~F} /$ molの通電を行ったとき得られた（Run 41）。

西鉛電極上でのヒドロニウムイオン $\left(\mathrm{H}_{3} \mathrm{O}^{+}\right)$, ニッケ ルイオン (II)，カドミウムイオン (II)，銅イオン (II) の電解還元は $\mathrm{C}_{4} \sim \mathrm{C}_{6}$ アルコールの添加によって阻害を受 けることが知られている ${ }^{9)}$. Fig.1 はまた, 白金電極の水 素発生反応に対古る活性が塭化車鉛の還元で低下し, 塩 化亚鉛の還元電位が n一ブタノ一の添加によって僅かなが ら龺側に移動したことを示している。これらの結果より， 電極の亜鉛イオンを還元する割合が増し，電極上への金 
Table 4 Electroreduction of the carbonyl compounds in the presence of zinc chloride.

\begin{tabular}{|c|c|c|c|c|}
\hline Run & Material & $\begin{array}{c}\text { Potential } \\
(-\mathrm{V} \text { vs. } \mathrm{Ag} / \mathrm{AgCl})^{\mathrm{a})}\end{array}$ & Product & $\begin{array}{l}\text { Yield } \\
(\%)\end{array}$ \\
\hline 44 & 4.Chloroacetophenone & $1.84,2.01$ & 1.(4-Chlorophenyl)ethanol & 92 \\
\hline 45 & $\alpha$-Chloroacetophenone & $0.78,1.40$ & $\alpha$-Chloro-1-phenylethanol & 17 \\
\hline 46 & Benzophenone & 1.78 & Benzhydrol & 47 \\
\hline 47 & 9-Fluorenone & 1. $28,2.10$ & 9-Hydroxyfluorene & 63 \\
\hline 48 & Cyclohexanone & $*$ & Cyclohexanol & 13 \\
\hline 49 & 4-Heptanone & * & 4.Heptanol & 3 \\
\hline 50 & Benzil & $1.13,1.93$ & Benzoin & 9 \\
\hline 51 & Benzaldehyde & 1.89 & Benzylalcohol & 97 \\
\hline 52 & Heptaldehyde & 1.96 & 1-Heptanol & 43 \\
\hline 53 & Zinc chloride & 1.45 & & \\
\hline
\end{tabular}

Electrolyses in a divided $\mathrm{H}$ type cell at $\mathrm{ca} .25^{\circ} \mathrm{C}$; Pt Cathode, $20 \mathrm{Fmol}^{-1}$ constant current density $\left(-16 \mathrm{~mA}^{-2}\right)$; Electrolyte : Substrate $(8.3 \mathrm{mmol})$ and $\mathrm{ZnCl} 2(16.8 \mathrm{mmol})$ in a mixed solvent $(2 \mathrm{M}-\mathrm{HCl}:$ EtOH $: \mathrm{n}-\mathrm{BuOH}=2.5: 1.0: 1.5 \mathrm{~V} / \mathrm{V})$ of $50 \mathrm{ml}$.

a) Determined from the current-potential curves on a Pt electrode $\left(0.7 \mathrm{M}(\mathrm{Bu})_{4} \mathrm{NI} / \mathrm{DMF}\right)$, at a sweep rate of $100 \mathrm{mVs}^{-1}$. * Unable to observe.

属要鉛の電析か增大されることが分かる。しかし，プロ

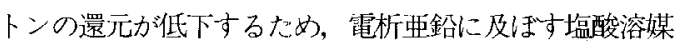
柔の作用は大きく働くだろう。また，刺鉛金属が活性を 示すことから考えて，還元反纫に伴う電極近傍のアルカ リ性の作用が考えられる。どちらの作用か強く影響を与 えるか明かではないが，電析要鈶はこれら液性の影響を 受けるだろう。一方，ブタノ一ルの添加による亜鉛イ才 ンの還元電位の卑側への移動は，亜鉛の電析量に影響を 与えるだろう。通電量の検討結果からも分かるように, n一ブタノールの添加は過剩量の通電下にあってもIIを選択 的に与えた。の結果は, n-ブタノールが界面活性物質と しての特性を持つことから考之て，金属亚鉛の電極表面 上への電析を阻害寸る効果が考之られ，酸性溶媒中への 遊離状態の電析をもたらしたことがIの高収率達成要因 の一々思える。

酸性水溶液中，金属要鉛によるケトン，アルデヒドの メチレン基，メチル基への変換をもたらす Clemmensen

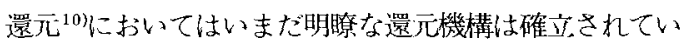
ないが，電子移動に先立つカルボニル酸素へのプロトン 化によって，カチオン化したカルボ二ル炭素に対して金 属严鉛からの電子移動か起こると考えられている。この 反応に対し亜鉛イオンか関与寸る可能性は考之にくい．

酸性溶液中，Iのプロトン化される程度は小さい11). また,カルボニル化合物が亜鉛イオンと錯形成 ${ }^{12,13) を す る ~}$ ことか知られている. Mairanovskii ら ${ }^{14}$ はポーラログ ラフィーによるフルオレノンの還元が曲鉛イオンとの錯 形成により容易になることを報告した，本反応において も I と亜鉛イオンとの間に同様な錯形成を考えることが
可能であろう，垛酸濃度の増大に伴う】の収率の減少は (Runs 10，32，33)過剩量に存在与る塩化物イオンが カルボニル基と亜䤪イオンとの間の錯形成を妨害した結 果と考えることが出来る．また，塩化要鉛を共存させた 酸性アルコール溶媒中，空温下でIの水素による還元反 応を試みたところ，反地は全く起こらなかった，酸性溶 液中，曲鉛粉末を共存させた化学反匛ではIIIを選択的に 与え, Risinger ら ${ }^{(5)}$ の結果と一致した。一定量の金属平 鉛交電析させるときの電流効率泣程酸の共存下て低下し， 電析亜鉛とプロトンとの反応走示㖫する結果か知られて いる ${ }^{16)}$ ここれらのことより，本反応におけるIと亜鉛イ オンとの錯形成は電析した亜鉛の溶解による活性な亜鉛 イオンによってもたらされると推察することが出来る.

詳細な還元機構について珄らかではななが，I と亚 鉛イオンの錯化合物に対守る電極からの直接電子移動な いしは Clemmensen 類似機構を考えることが可能である j.

\section{3 他のカルボニル化合物に対する還元反応}

従来，アセトフェノンを始好をするカルボ二ル化合物 の還元反応においては白金電極のような水素過電圧の小 さい電極の使用は電流効摔が非常に悪く，または反応が 全く進行せず不墑と考えられていた，本報の結果は，こ の上うな特性を持つ白金電極がカルボニル化合物の選択 的還元反心に效して効果的に使用出来ることを示惨した。 そこでこのことを確証するべく本反心を種々のカルボ ニル化合物に対して試みた。結果を Table 4 に記載した。 主としてケトン，アルデヒドについて検討しところ， いずれの基質についても相当するアルコールが 3〜97\% 
の收率で得られた。カルボル基の還元の難易性が Hammet 則に潐じて隣接する置換基の影響を受けると仮定す ると，各種アルコールの収率は基質の還元電位と関連が あると考之られる。そこで，コウ化テトラブチルアンモ 二ウムを支持塩とする無水ジメチルホルムアミド溶液中， 各種基質の還元電位を測定し，反応結果とこれを比較検 討したところ，明暸な相関関係は認められなかった。高 選択性，高収㳯に及ぼす影響は基質の構造的な要菜なら びに還元可能な他の官能基の存在の要素か強く働いてい ることが考えられた。

\section{4 結 論}

従来カルボ二ル化合物の笪解還元反忘には不適と考え られていた手電極を使用し，Iの電解還元反応を塩酸 水ーアルコールの混合溶媒中て盐化曲銆の共存下に検討し たところ，塩化垔鋿はIIの牛成を促進させる特性を有す ることが分かった．合成的な検討のもとにその最適電解 条件を検討した結果，IIを $97 \%$ の收率て得ることが出来 た．本成志在他のケトン，アルデヒド類に対して適用さ せたところ，相当するアルコールが基質の構造によって 3〜97\%の仪率てて得られた.塩化带鉛のIIの選択的生成に 対する促進効果は電析业鉛の溶解によってもたらきれる 活性な平鉛イオンとIの間の錯形成か強く関与すると推 定した.

\section{文 献}

1) M. Perrin, P. Pouillen, G. Mousset, and P. Martinet, Tetrahedron, 36, 221 (1980).

2) (a) P. Zuman, D. Barnes, and A. R. Kejharova, Disc. Faraday Soc., 45, 202 (1968) ; (b) B. E. Conway, E. J. Rudd, and L. G. M. Gordon, Disc. Faraday Soc., 45, 87 (1968).
3) D. W. Sopher and J. H. P. Utley, J. Chem. Soc. Chem. Commun., 1979, (1087).

4) D. W. Sopher and J. H. P. Utley, J.Chem. Soc. Perkin Trans., II, 1361 (1984).

5) F. Fournier, J. Berthelot, and Y. L. Pascal, Tetrahedron, 40, 339 (1984).

6) F. Fournier, J. Berthelot, and Y. L. Pascal, Can. J. Chem., 61, 2121 (1983).

7) Y. Ikeda and E. Manda, Chem. Lett., 1989, 839.

8) M. Petit, A. Mortreux, and F. Petit, J. Chem. Soc. Chem. Commun., 1984, 341.

9) B. N. Afanasev and N. V. Gogolev, Elektrokhimiya, 20, 48 (1984).

10) E. L. Martin, “Organic Reactions" R. Adams, Ed., Vol. I, Jone Wiley \& Sons, Inc., New York, N.Y., P.155 (1942).

11) G. Culbertson and R. Pettit, J. Am. Chem. Soc, 85, 741 (1963).

12) H. R. Mahler and J. Douglas, J. Am. Chem. Soc., 79, 1159 (1957).

13) M. L. Khidekel, A. S. Astakhova, N. F. Dmitrieva, S. N. Zelenin, G. I. Kozub, G. A. Koikaris, and Yu. A. Shvetsov, Zh. Obshch. Khim., 37, 1483 (1967).

14) S. G. Mairanovskii, V. P. Gultyai, N. G. Bogatova, N. V. Surikova, and L. B. Reznik, Elektrokhimiya, 14, 1075 (1978).

15) G. E. Risinger, J. M. Garrett, and J. A. Winkler, Recl. Trav. Chim. Pays-Bas, 83, 873 (1964).

16) D. Pletcher, M. Razaq, and C. D. Smilgin, J. Appl. Electrochem., 11, 601 (1981). 